\title{
Development of a Finite Element Model of the Human Cervical Spine
}

\section{Sonlu Eleman Yöntemi ile Servikal Omurga Modelinin Oluşturulması}

\author{
Iman ZAFARPARANDEH ${ }^{1}$, Deniz U. ERBULUT ${ }^{1}$, Ismail LAZOGLU ${ }^{1}$, Ali Fahir OZER ${ }^{2}$ \\ ${ }^{1}$ Koc University, College of Engineering, Department of Mechanical Engineering, Istanbul, Turkey \\ ${ }^{2}$ Koc University, School of Medicine, Department of Neurosurgery, Istanbul, Turkey
}

Corresponding Author: Deniz U. ERBULUT / E-mail: erbulut.deniz@gmail.com

\begin{abstract}
The finite element model has been used as an effective tool in human spine biomechanics. Biomechanical finite element models have provided basic insights into the workings of the cervical spine system. Advancements in numerical methods during the last decade have enabled researchers to propose more accurate models of the cervical spine. The new finite element model of the cervical spine considers the accurate representation of each tissue regarding the geometry and material. The aim of this paper is to address the new advancements in the finite element model of the human cervical spine. The procedures for creating a finite element model are introduced, including geometric construction, material-property assignment, boundary conditions and validation. The most recent and published finite element models of the cervical spine are reviewed.
\end{abstract}

KEYWORDS: Finite element modelling, Cervical spine, Numerical method

öz

Sonlu eleman yöntemi efektif bir araç olarak omurga biyomekaniğinde yaygın kullanılmaktadır. Servikal omurga içerisinde meydana gelebilecek biyomekanik değişimlerin incelenmesine fırsat verebilmektedir. Geçtiğimiz on yıl içerisinde, geliştirilmiş olan nümerik metodlar sayesinde, daha gerçekçi omurga modellerinin çıkarılması sağlanmıştır. Günümüzde, servikal omurga modellerinde kullanılan geometri ve malzeme özellikleri olabildiğince gerçeğe yakın oluşturulabilmektedir. Bu makalenin amacı, sonlu eleman yöntemi kullanılarak insan servikal modellinin oluşturulmasını örneklerle açıklamaktır. Servikal omurga modelinin sonlu eleman yöntemi ile oluşturulmasının her bir adımı detaylı ele alınmıştır. Literatürde en son yayınlanan servikal omurga sonlu eleman modelleri incelenmiş ve karşılaştırılmıştır.

ANAHTAR SÖZCÜKLER: Sonlu eleman modelleme, Servikal omurga, Numerik analiz

\section{INTRODUCTION}

The cervical region is a frequent site of injury in the spinal column. Most of the injuries are soft tissue injuries and are caused by automobile accidents. To understand the underlying mechanisms of injury and dysfunction, biomechanical models are introduced as versatile tools. These models may be helpful for the prevention, diagnosis, and treatment of clinical conditions. The finite element (FE) model is one of the critical biomechanical models that provide basic insights into the workings of the cervical spine. Physical models, in vitro models and in vivo models are the other available biomechanical models for obtaining important information regarding cervical spine biomechanics in response to various treatments. However, in comparison with FE models, these models are limited by their inability to predict, for instance, the internal response of the cervical spine to localized stress and strain fields (32). Continuous advancements in numerical techniques and computer technology have made the finite element method an effective tool in human spinal biomechanics. Finite element modeling provides researchers with different perspectives of the spinal biomechanics, that is, stress analysis; load sharing under normal, pathologic, and stabilized conditions; and the design of anthropomorphic test devices $(47,49)$. To achieve reliable results, it is crucial to use accurate anatomy, material properties, boundary and loading conditions and validation against the appropriate experimental data.

In earlier FE models, the cervical column was represented by a combination of simple rigid masses connected by beam and spring elements signifying intervertebral discs, ligaments, facet joints and muscles $(2,5)$. The simple rigid masses considered as vertebrae do not produce realistic results. Thereafter, detailed FE models were suggested by researchers, $(13,24,41,48)$. In 1996, Yoganandan et al. (48) proposed a detailed 3D FE model of the C4-C6 segment, including all of the important anatomic features such as the facet articulation surfaces and uncinate processes. The researchers used close-up computed tomography scans to create an anatomically accurate geometry for the vertebrae. The model was validated against published in vitro experimental results under axial compression only. The models that were proposed until 1998 were limited by their 
inability to predict the correct biomechanical response in complex loading modes, including axial rotation and lateral bending. In 1998, Goel et al. (13) developed a C5-C6 motion segment of the cervical spine, which was validated in all of the loading modes (including axial rotation and lateral bending) and published for the first time. Nonlinear ligament definition, a fully composite intervertebral disc, a fluid nucleus and Luschka's joint were included in this model. Teo et al. (41) developed a 3D FE model of C4-C6 to study the role of ligaments, facets and the disc nucleus on instability. Their model used a digitizing technique to obtain the accurate geometry of each vertebra. The model assumed symmetry about the mid-sagittal plane. The validation was conducted using three load configurations, including axial compression, flexion and extension.

The abovementioned, proposed models predicted the internal stresses, strains and biomechanical responses under complex loading modes. However, these models consisted of either one or two spinal motion segments, or they did not consider all features of the cervical spine. Therefore, the proposed models were insufficient to provide realistic responses of the physical multi-levels (more than two levels) of the spinal column (50).

Based on the type of FE analysis in cervical spine biomechanics, whether static or dynamic, the necessity of considering the full cervical or multi-segment models has been defined by researchers (49). In dynamic simulations, the vertebrae are usually considered as rigid bodies that are connected by discs and ligaments that are modeled as springs. These dynamic models include the skull and all of the vertebrae and discs $(1,25,39)$. In contrast, models that are proposed for static simulation present more details of the geometry and material properties of the cervical spine $(4,24,27,48)$. However, these models do not include all segments of the cervical spine. More recently, full cervical spine FE models were proposed by several investigators $(7,19,36,50)$ for static analysis. In 2006, Zhang et al. (50) developed a comprehensive FE model of the C0-C7 cervical spine and head. They validated the model under $1.0 \mathrm{Nm}$ pure moment applied to the skull in different directions, i.e., flexion, extension, axial rotation and lateral bending. All of the main spinal components, such as the cortical bone, cancellous bone, posterior elements, disc annulus, disc nucleus and endplate were appropriately simulated.

The objective of this study is to review the recent advancements in FE modeling of the cervical spine. The structure of this review is based on the procedure of FE modeling of the cervical spine. The cervical spine FE modeling procedure consists of the following steps: construction of vertebra, intervertebral disc and ligaments; assignment of material properties and boundary conditions; and validation by different in vitro studies.

\section{FE MODEL of the CERVICAL SPINE}

In general, the FE model of any structure consists of a finite number of "elements" that interact at their points of attachment, called "nodes". Using these elements, the modeling of complex irregular geometries, as in biomedical cases, is feasible. In the FE model of the cervical spine, various types of elements with different geometric forms (bars, plates, blocks, etc.) may be used to represent the cervical spine components (14).

A finite element model is composed of three aspects: the geometric representation, the material representation (constitutive laws) and the boundary conditions (loading and restraints). First, it is advisable to define the actual geometry of the cervical spine as closely as possible. One of technique, known as computed tomography (CT), is commonly used to provide the appropriate 3D bone details of the spine. Using CT data enables viewing a subject based upon the specific requirements of the problem $(7,13,19,21,22,48)$. As an alternative to the CT technique, direct digitization of dried or embalmed cadaveric bones may provide excellent geometric fidelity at the expense of an extensive period of time $(15,26,27,28,40,41,50)$. Another major concern in FE modeling of the spine involves the material properties of the spinal components, which vary broadly, even within a specific structure. These properties have predominantly been identified via in vitro studies $(13,45)$. Finally, applying boundary conditions similar to those of in vitro studies prepare the model for simulation.

\section{Model Geometry and Mesh}

The first step in FE modeling of the cervical spine is obtaining the geometry of all the different components. The geometry of the cervical spine may be defined by three different groups, including vertebrae, intervertebral discs, and ligaments and facet joints. This type of division is based on the functionality of each spinal component. Various methods have been introduced in the literature to generate the geometry of each group. The vertebral geometry may be obtained via CT scan data, while discs are usually created as solid volumes filling the space between two vertebrae. Ligaments are modeled based on their origin and insertion. Facet-joint modeling depends on the type of element used. Generally, geometry construction and mesh generation are two interdependent steps. In certain cases, the spinal component is modeled by using the appropriate mesh type without geometric constructions.

The vertebral geometry is the most complicated part of model construction and consists of many free-form surfaces, such as facet surfaces and the surface upon which the disc is located. Thesefree-form surfaces increase the time required to generate the mesh. The vertebral meshing time varies and depends on the type of mesh. There are two commonly used element types for spinal models. Tetrahedral elements are easier to generate on the curvy surfaces of vertebrae but are limited by their inability to simulate appropriate material properties (31). Hexahedral elements, or eight-node "brick" elements, are accepted as the preferred element type for 3D nonlinear analysis (20). However, this type of element is computationally 
expensive to solve and may cause discontinuities of the edges if the surface smoothing is not sufficiently performed. Zhang et al. (50) obtained the vertebral geometry using a flexible digitizer from an embalmed 68-year-old cadaveric specimen (C1-C7). The researchers used eight-node "brick" elements for the vertebrae (Figure 1). Del Palomar et al. (7) used computed tomography scan data from a 48-year-old man to construct the 3D surface geometry of the cervical vertebrae. The vertebrae were considered rigid bodies; thus, only the exterior surfaces of the vertebrae were meshed using surface elements (triangles and quadrilaterals) (Figure 2). Panzer et al.
(36-38) used a 3D dataset available in literature (8) to construct the geometry of the full cervical spine. They compared the vertebral geometry with the existing anatomical studies. $3 \mathrm{D}$ hexagonal elements were used to generate mesh on cancellous bone, while cortical bone and endplates of the vertebrae were meshed with two-dimensional quadrilateral elements (Figure 3). Kallemeyn et al. $(19,20)$ proposed mesh generation methods using multi-block techniques to simplify the procedure required to create an FE model of the cervical spine using only hexahedral elements. They obtained the vertebral geometry of a specimen from a 74-year-old male
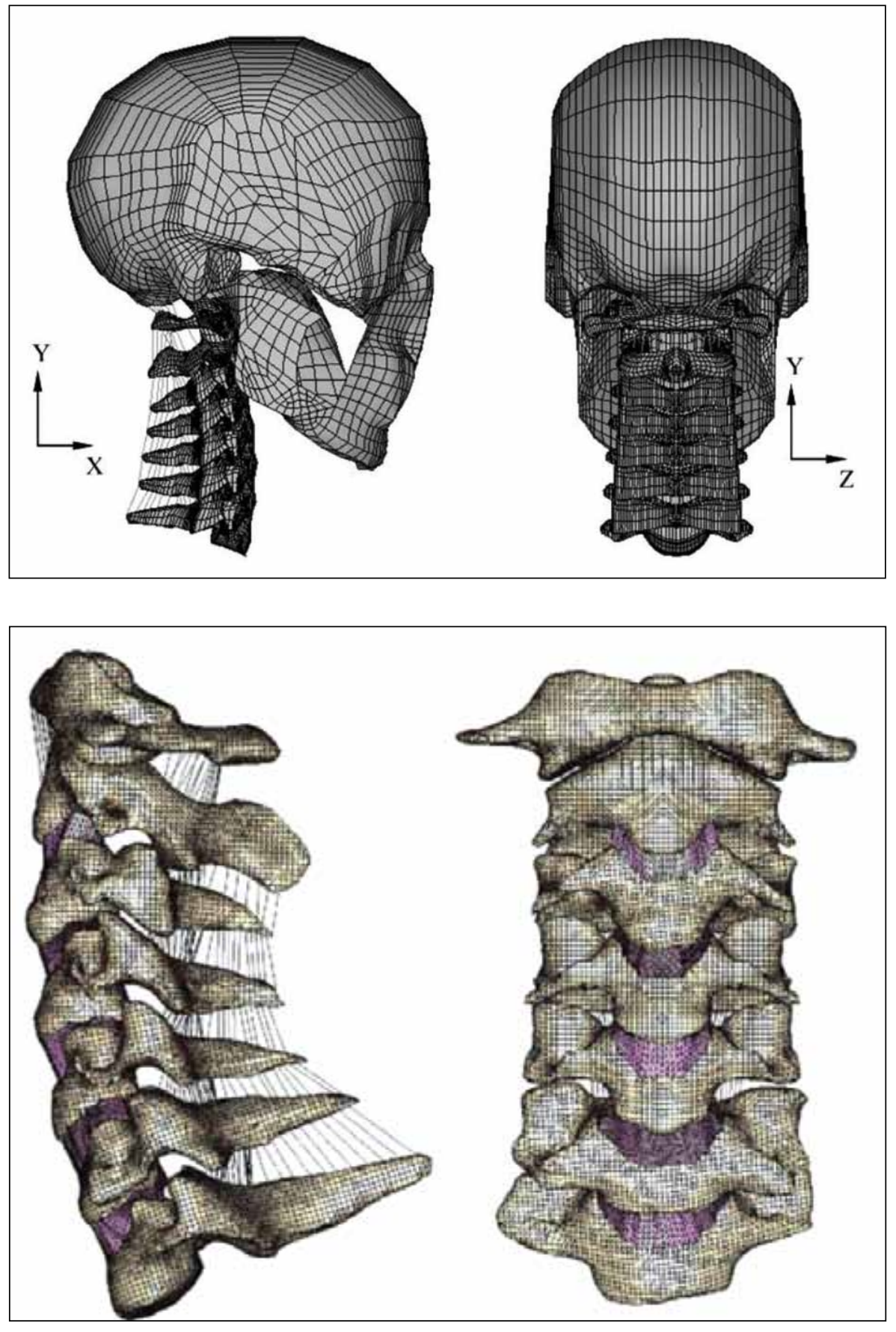

Figure 1: Finite element model of the full cervical spine, developed by Zhang et al (50) (Reprinted with permission).
Figure 2: 3D finite element model of the cervical spine, developed by Del Palomar et al (7) (Reprinted with permission). 


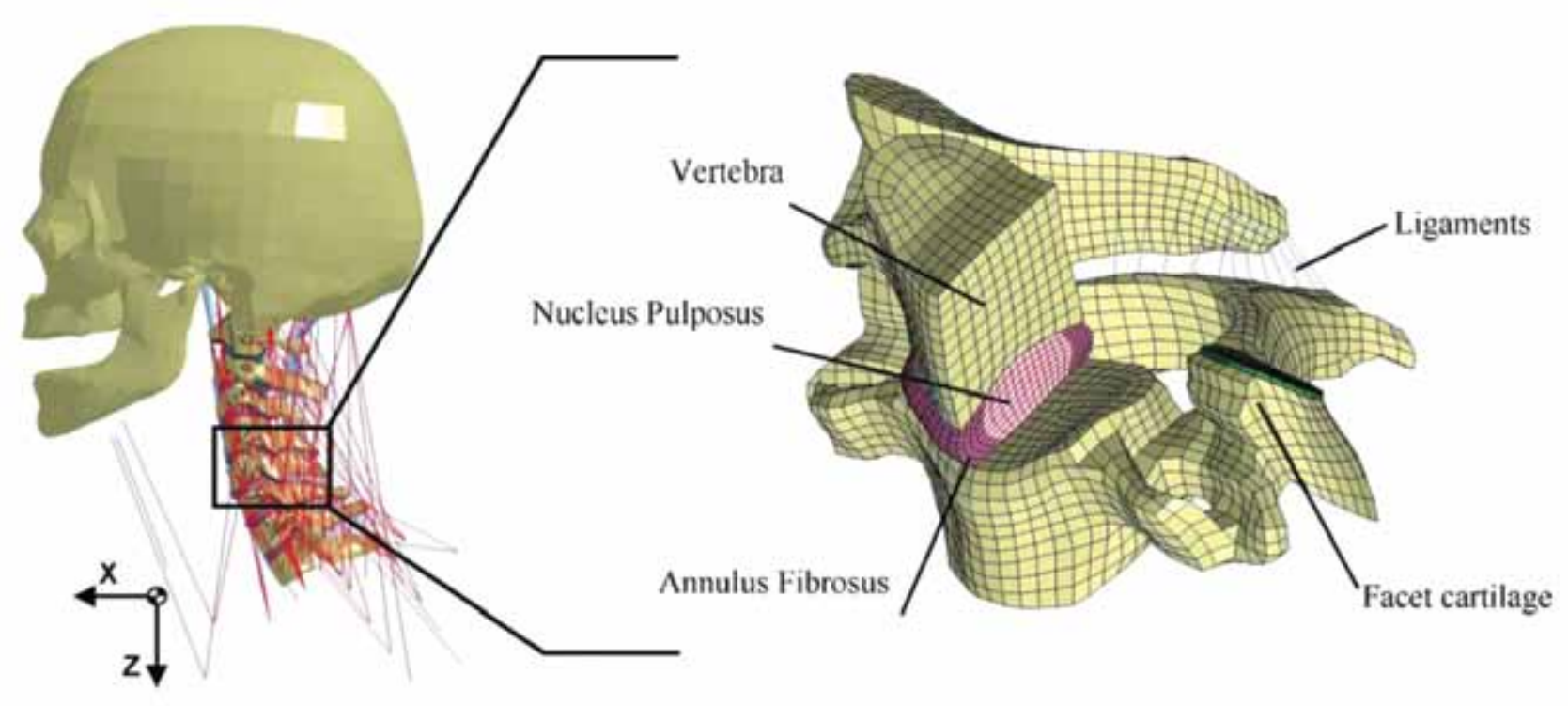

Figure 3: Finite element model of the full cervical spine, used for studying frontal crash simulation (36) (Reprinted with permission).

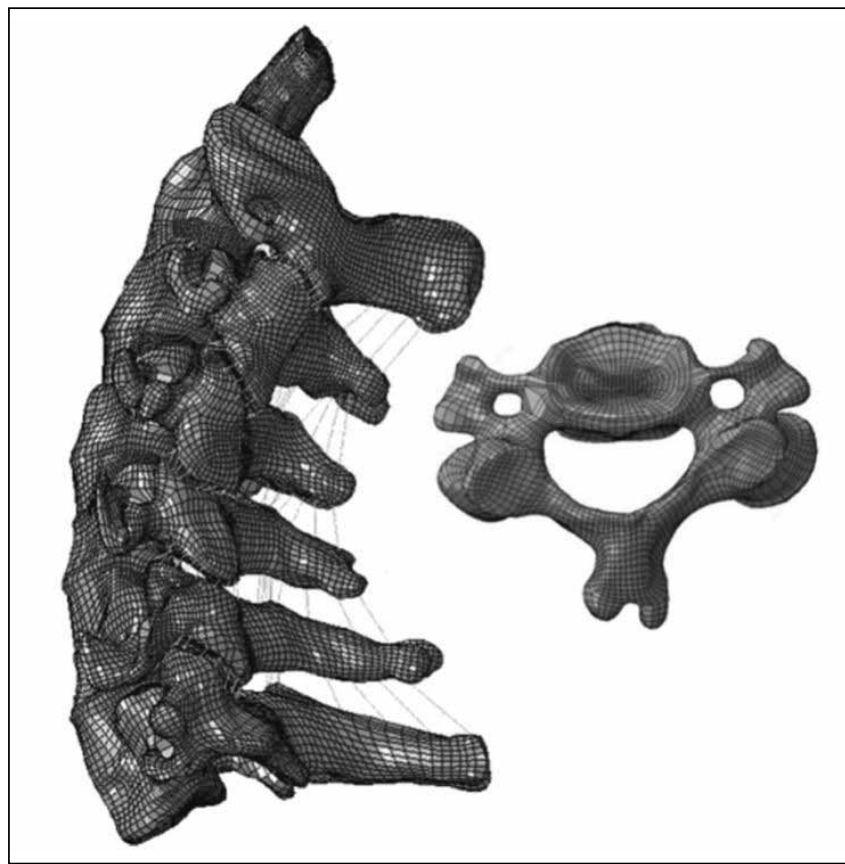

Figure 4: Finite element model of the cervical spine, as developed by Kallemeyn et al (19) (Reprinted with permission).

cadaver (Figure 4). Ha (16) developed a 3D FE model of the C3-C6 cervical segment using computed tomography. The CT scan data were used to construct non-uniform rational B-splines (NURBS) CAD surfaces of the vertebrae. He used eight-node shell elements for the cortical bone and twentynode solid elements for the cancellous bone (Figure 5). In a recent study, Erbulut et al. (10) developed an FE model of full cervical spine (C2-T1) using the accurate geometry from $\mathrm{CT}$ data (Figure 6). The model was asymmetric about mid-sagittal plane. The multi-block approach introduced by Kallemeyn

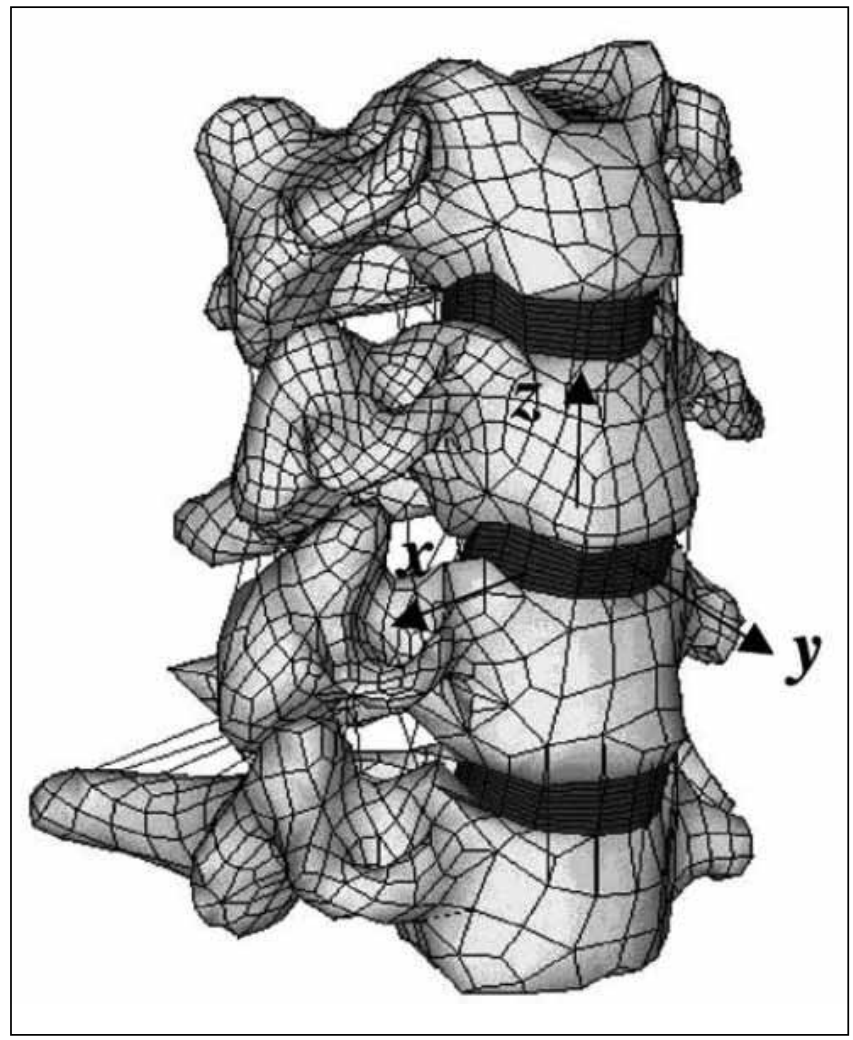

Figure 5: Finite element model of the lower cervical spine, developed by $\mathrm{Ha}$ (16) (Reprinted with permission).

et al. (20) was used to create hexahedral mesh on surface of vertebrae and discs. Reviewing the recent FE models of the cervical spine reveals that $\mathrm{CT}$ scan data constitute a reliable and easily obtainable source for constructing the vertebral geometry. Furthermore, researchers are exerting additional 


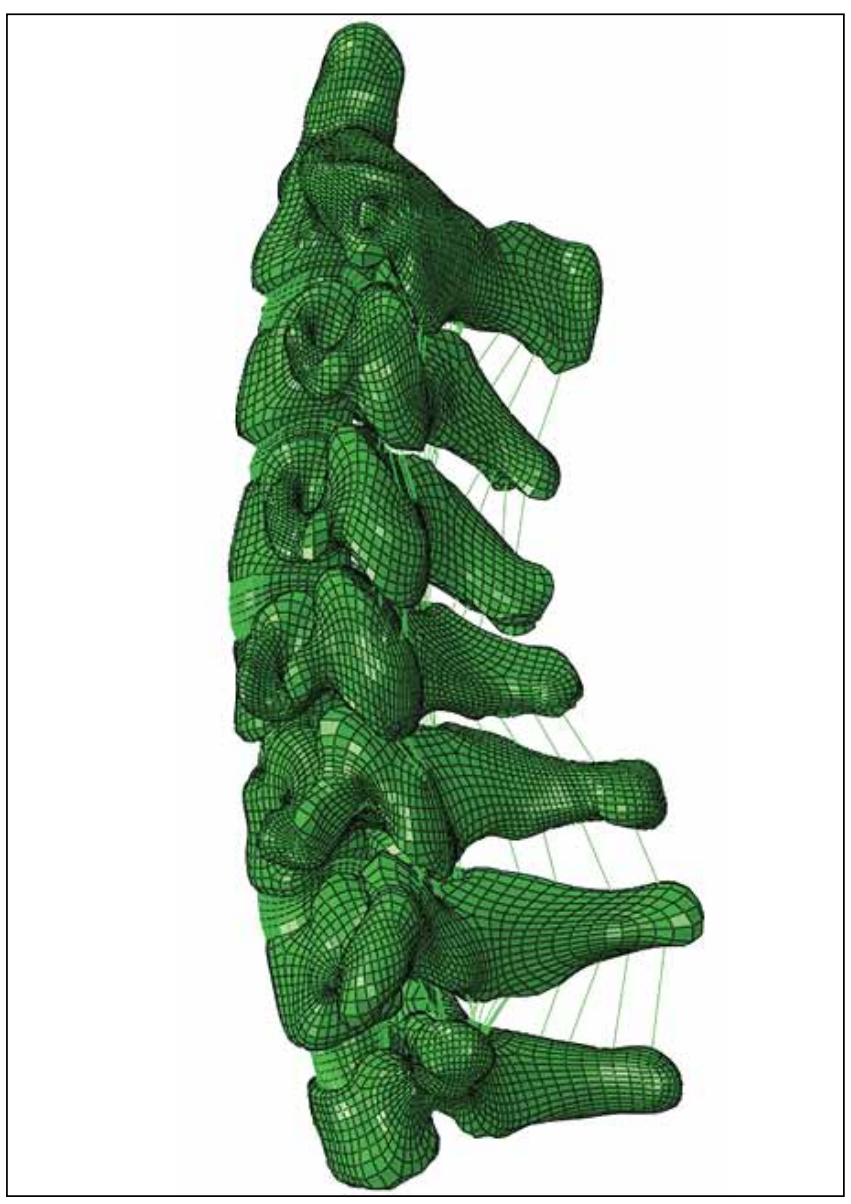

Figure 6: Finite element model of full cervical spine (C2-T1) developed by Erbulut et al. (10) (Reprinted with permission).

effort to generate hexahedral elements on the complex geometry of the vertebrae.

Generally, the disc geometry is created after obtaining the vertebral geometry. Intervertebral discs are modeled as solid volumes filling the space between two vertebrae while not exceeding the outer boundary of the vertebral bodies. Several studies $(7,16,38,50)$ defined the disc geometry based on the anterior and posterior thicknesses reported in the literature (11). Kallemeyn et al. (20) generated the mesh between two vertebrae without creating the surface disc geometry. The hexahedral element is the most common type of element used to generate mesh on discs $(16,19,38,44,50)$, although tetrahedral elements have also been employed $(7,23)$.

The geometry of ligaments is defined based on their origin/ insertion, length and cross-sectional area (45). In general, the proposed ligament models use the same geometric properties as those published previously $(3,34,35,46)$. Five different groups of ligaments are considered in FE modeling of the cervical spine: anterior longitudinal ligament (ALL), posterior longitudinal ligament (PLL), ligamentum flavum (LF), interspinous ligament (ISL) and capsular ligament (CL). Different types of elements have been used for simulating the behavior of ligaments, including spring/cable and membrane types. Del Palomar et al. (7), Kallemeyn et al. $(19,20)$ and Goel et al. (13) used 3D truss elements acting only under tension. Zhang et al. (50) used two-node link elements, which only permitted axial force transmission.

The last step in creating the geometry and mesh for the FE model of the cervical spine is modeling of the facet or zygapophysial joints. The anatomy of this joint is composed of three parts: cartilage, synovial membrane and synovial fluid. The space between the two cartilages is usually defined by sliding or gap elements $(14,22)$. In certain FE models, facet joints are treated as a surface-to-surface contact problem (17, $21,50)$. Panzer et al. (38) used a squeeze-film-bearing model to represent the synovial fluid and hexagonal elements to simulate the articular cartilage.

\section{Material Properties}

The second most important aspect of a finite element model is the definition of material properties of the individual components. Non-homogeneity, anisotropy and material nonlinearities are prevalent within the cervical structure, although in some instances, linear assumptions may be appropriate for the simulation. For example, linear models have been used to determine the sites of crack initiation during vertebral collapse (6). The material property data of the human cervical spine are developed through controlled laboratory experiments. The wide variation in the material properties used in finite element models generally arises from the inherent biologic variability in the experimental work. This variation causes inconsistency between the material definition in FE models and cadaver experiments.

To assign the material properties, the vertebral mesh is divided into four different groups based on the mineral density of the bone. These groups are cortical bone, cancellous bone, the posterior part and endplates. In most of the FE models, the isotropic elastic model is used to simulate the material properties of all four vertebral parts $(13,16,19,20,26-28,40$ $44,50)$. Panzer et al. (38) used an orthotropic elastic material model for cancellous bone to investigate the increase in stiffness in the superior-inferior direction rather than in the transverse direction due to the trabecular structure. Del Palomar et al. (7) modeled the vertebrae as rigid bodies because the researchers focused on the soft tissue response in their model.

The definition of the intervertebral disc causes many complications in finite element modeling of the cervical spine. The complex geometry of the intervertebral disc consists of the annulus fibrosus and nucleus pulposus. The annulus is reinforced with collagen fibers, while the nucleus is composed of a fluid material. Various material models have been proposed for modeling the disc structure. One of the accurate FE models focusing on intervertebral-discmaterial modeling was proposed by Del Palomar et al. (7). To model the annulus, they used a strain energy function with two family of fibers proposed previously (18) and adjusted 
the material parameters to the experimental results of Ebara et al. (9). To model the nucleus, the researchers used a hyperelastic incompressible Neo-Hookean model. Panzer et al. (38) employed the isotropic material strain-energy function proposed by Hill (1978) (17), thereby representing the annulus. Five pairs of quadrilateral layers were embedded in the annulus, thereby representing the fibers. The nucleus was modeled using the fluid elements. Teo et al. (41) modeled the intervertebral disc as three layers: two layers (superior and inferior) of 0.5 thickness as the endplates and the encasing middle layer of intervertebral disc, which consisted of the annulus and nucleus. The simple isotropic elastic model was used to represent the material property of both the annulus and the nucleus.

As uniaxial structures, the role of ligaments is to resist tensile or distractive forces. The ligaments are often treated as simple elastic beam elements. A standard beam formulation for these elements imposes non-physiologic loading during compression, and tension-only cable elements are preferred $(7,20,41,50)$.

\section{BOUNDARY and LOADING CONDITIONS}

After constructing the model geometry and mesh and assigning material properties to each spinal component, the last step in creating a FE model of the cervical spine is defining the appropriate boundary conditions. Generally, the boundary conditions are specified on the superior and inferior ends of the FE model. To achieve this boundary condition, every node lying on the inferior surface of the lowermost vertebra is restrained to zero displacement. In quasi-static studies, an axial compressive load is applied on the superior part of the model to represent the weight of the skull (50). Other types of loading, including tension, compression, shear, flexion, extension, lateral bending and axial rotation can be applied on the superior aspect of the uppermost vertebra, and a follower load that simulates the body weight may be applied to each vertebra (47).

\section{VALIDATION}

The validation process is the last step in the FE analysis, after creating the model. The goal of validation is to assess the capability of the FE model in predicting the model response to real-life conditions. This assessment is made by comparing the predictive results of the model and cadaver experiments. The required experimental data for validating the FE model of the cervical spine may be obtained from the reported in vitro or cadaveric studies. A large variety of in vitro studies are available in the literature $(12,29,30,33,43)$.

\section{REFERENCES}

1. Camacho DL, Nightingale RW, Myers BS: Surface friction in near-vertex head and neck impact increases risk of injury. Journal of Biomechanics 32:293-301, 1999

2. Chang H, Gilbertson LG, Goel VK, Winterbottom JM, Clark CR, Patwartdhan A: Dynamic response of the occipitoatlantoaxial (C0-C1-C2) complex in right axial rotation. Journal of Orthopaedic Research 10:446-453, 1992
3. Clark CR: The cervical spine. Philadelphia: Lippincott-Raven, 1998

4. Clausen JD, Goel VK, Traynelis VC, Scifert J: Unicinate process and Luschka joints influence the biomechanics of cervical spine: Quantification using a finite element model of the C4C5 segment. Journal of Orthopaedic Research 15:342-347, 1997

5. Coffee MS, Edwards WT, Hayes WC, White AAl: Biomechanical properties and strength of the human cervical spine. Transactions of ASME Bioengineering Division 3:71-72, 1987

6. Crawford RP, Cann CE, Keaveny TM. Finite element models predict in vitro vertebral body compressive strength better than quantitative computed tomography. Bone 33:744-750, 2003

7. Del Palomar AP, Calvo B, Doblaré $M$ : An accurate finite element model of the cervical spine under quasi-static loading. Journal of Biomechanics 41:523-531, 2008

8. Deng YC, Li X, Liu Y: Modeling of the human cervical spine using finite element techniques. In: Proceedings from the 43rd Stapp Car Crash Conference, 1999

9. Ebara S, latridis JC, Setton LA, Foster RJ, Mov VC, Weidenbaum M: Tensile properties of nondegenerate human lumbar annulus fibrosus. Spine 21:452-461, 1996

10. Erbulut DU, Zafarparandeh I, Lazoglu I, Ozer AF: Application of an asymmetric finite element model of the C2-T1 cervical spine for evaluating the role of soft tissues in stability. Medical Engineering \& Physics 2014

11. Gilad I, Nissan M: Study of vertebra and disc geometric relations of the human cervical and lumbar spine. Spine 11(2): 154-157, 1986

12. Goel VK, Clark CR, Harris KG, Schulte KR: Kinematics of the cervical spine: Effects of multiple total laminectomy and facet wiring. Journal of Orthopaedic Research 6:611-619, 1988

13. Goel VK, Clausen JD: Prediction of load sharing among spinal components of a C5-C6 motion segment using finite element approach. Spine 23(6):684-691, 1998

14. Goel VK, Gilbertson LG: Spine update: Applications of the finite element method to thoracolumbar spinal research past, present, and future. Spine 20:1719-1727, 1995

15. Guo LX, Teo EC, Lee KK, Zhang QH: Vibration characteristics of the human spine under axial cyclic loads: Effect of frequency and damping. Spine 30:631-637, 2005

16. Ha SK: Finite element modeling of multi-level cervical spinal segments (C3-C6) and biomechanical analysis of an elastomer-type prosthetic disc. Medical Engineering \& Physics 28:534-541, 2006

17. Hill R: Aspects of invariance in solid mechanics. Advances in Applied Mechanics 178:1-75, 1978

18. Holzapfel GA: Nonlinear solid mechanics. New York: Wiley, 2000

19. Kallemeyn N, Gandhi A, Kode S, Shivanna K, Smucker J, Grosland N: Validation of a C2-C7 cervical spine finite element model using specimen-specific flexibility data. Medical Engineering \& Physics 32:482-489, 2010 
20. Kallemeyn N, Tadepalli SC, Shivanna K, Grosland N: An interactive multiblock approach to meshing the spine. Computer Methods and Programs in Biomedicine 95: 227-235, 2009

21. Kumaresan S, Yoganandan N, Pintar FA: Finite element modeling approaches of human cervical spine facet joint capsule. Journal of Biomechanics 31:371-376, 1998

22. Kumaresan S, Yoganandan N, Pintar FA, Maiman DJ: Finite element modeling of the cervical spine: Role of intervertebral disc under axial and eccentric loads. Medical Engineering \& Physics 21:689-700, 1999

23. Li Y, Lewis G: Influence of surgical treatment for disc degeneration disease at $\mathrm{C} 5-\mathrm{C} 6$ on changes in some biomechanical parameters of the cervical spine. Medical Engineering \& Physics 32(6): 595-603, 2010

24. Maurel N, Lavaste F, Skalli W: A three-dimensional parametrized finite element model of the lower cervical spine. Study of the influence of the posterior articular facets. Journal of Biomechanics 30(9): 921-931, 1997

25. Meyer F, Bourdet N, Deck C, Willinger R, Raul JS: Human neck finite element model development and validation against original experimental data. Stapp Car Crash Journal 48: 177-206, 2004

26. Ng HW, Teo EC: Influence of preload magnitudes and orientation angles on the cervical biomechanics. A finite element study. Journal of Spinal Disorders \& Techniques 18(1): 72-79, 2005

27. Ng HW, Teo EC: Nonlinear finite element analysis of the lower cervical spine (C4-C6) under axial loading. Journal of Spinal Disorders 14:201-210, 2001

28. Ng HW, Teo EC, Lee KK, Qiu TX: Finite element analysis of cervical spinal instability under physiologic loading. Journal of Spinal Disorders and Techniques 16(1):55-65, 2003

29. Nightingale RW, Carol Chancey V, Ottaviano D, Luck JF, Tran $L$, Prange $M$, Myers BS: Flexion and extension structural properties and strengths for male cervical spine segments. Journal of Biomechanics 40:535-542, 2007

30. Nightingale RW, Winkelstein BA, Knaub KE, Richardson WJ, Luck JF, Myers BS: Comparative strengths and structural properties of the upper and lower cervical spine in flexion and extension. Journal of Biomechanics 35:725-732, 2002

31. O'reilly MA,Whyne CM:Comparison of computed tomography based parametric and patient-specific finite element models of the healthy and metastatic spine using a mesh-morphing algorithm. Spine 33(17):1876-1881, 2008

32. Panjabi MM: Cervical spine models for biomechanical research. Spine 23(24): 2684-2699, 1998

33. Panjabi MM, Crisco JJ, Vasavada A, Oda T, Cholewicki J, Nibu $\mathrm{K}$, Shin E: Mechanical properties of the human cervical spine as shown by three-dimensional load-displacement curves. Spine 26:2692-2700, 2001

34. Panjabi MM, Oxland TR, Parks EH: Quantitative anatomy of cervical spine ligaments. Part 1. Upper cervical spine. Journal of Spinal Disorders 4(3):270-276, 1991
35. Panjabi MM, Oxland TR, Parks EH: Quantitative anatomy of cervical spine ligamnets. Part 2. Middle and lower cervical spine. Journal of Spinal Disorders 4:277-285, 1991

36. Panzer BM, Fice BJ, Cronin SD: Cervical spine response in frontal crash. Medical Engineering \& Physics 33:1147-1159, 2011

37. Panzer MB: Numerical modelling of the human cervical spine in frontal impact in mechanical engineering. University of Waterloo, 2006

38. Panzer MB, Cronin DS: C4-C5 segment finite element model development, validation, and load-sharing investigation. Journal of Biomechanics 42:480-490, 2009

39. Stemper BD, Kumaresan S, Yoganandan N, Pintar FA: Head-neck finite element model for motor vehicle inertial impact: Material sensitivity analysis. Biomedical Sciences Instrumentation 39:189-193, 2000

40. Teo EC, Ng HW: The biomechanical response of lower cervical spine under axial, flexion and extension loading using FE method. International Journal of Computer Applications in Technology 21:8-15, 2004

41. Teo EC, Ng HW: Evaluation of the role of ligaments, facets and disc nucleus in lower cervical spine under compression and sagittal moments using finite element method. Medical Engineering \& Physics 23:155-164, 2001

42. Teo JCM, Chui CK, Wang ZL, Ong SH, Yan CH, Wang SC, Wong HK, Teoh SH: Heterogeneous meshing and biomechanical modeling of human spine. Medical Engineering \& Physics 29(2):277-290, 2007

43. Wheeldon JA, Pintar FA, Knowles S, Yoganandan N: Experimental flexion/extension data corridors for validation of finite element models of the young, normal cervical spine. Journal of Biomechanics 39:375-380, 2006

44. Wheeldon JA, Stemper BD, Yoganandan N, Pintar FA: Validation of a finite element model of the young normal lower cervical spine. Annals of Biomedical Engineering 36: 1458-1469, 2008

45. Yoganandan N, Kumaresan S, Pintar FA: Biomechanics of the cervical spine. Part 2: Cervical spine soft tissue responses and biomechanical modeling. Clinical Biomechanics 16:1-27, 2001

46. Yoganandan N, Kumaresan S, Pintar FA: Geometric and mechanical properties of human cervical spine ligaments. Journal of Biomechancial Engineering 122:623-629, 2000

47. Yoganandan N, Kumaresan S, Voo L, Pintar FA: Finite element application in human cervical spine modeling. Spine 21(15):1824-1834, 1996

48. Yoganandan N, Kumaresan S, Voo L, Pintar FA, Larson SJ: Finite element modeling of the C4-C6 cervical spine unit. Medical Engineering \& Physics 18:569-574, 1996

49. Zafarparandeh I, Lazoglu I: Application of the finite element method in spinal implant design and manufacture. J.P. Davim (ed). The design and manufacture of medical devices. Woodhead Publishing, 2012

50. Zhang QH, Teo EC, Ng HW, Lee VS: Finite element analysis of moment-rotation relationships for human cervical spine. Journal of Biomechanics 39:189-193, 2006 